Bartın University Journal of Faculty of Economics and Administrative Sciences, 2021, Volume 12, Issue 24

E-ISSN: 2148-2497

https://dergipark.org.tr/tr/pub/bartiniibf

Araştırma Makalesi, Gönderim Tarihi: 29.07.2021; Kabul Tarihi: 13.09.2021

DOI:10.47129/bartiniibf. 975975

\title{
Barter Sistemi: Türkçe Literatürde Yapılmış Çalışmalar Üzerine Bir İnceleme
}

\author{
Öğr. Gör. Ömer KESKİN \\ Van Yüzüncü Yıl Üniversitesi, Özalp Meslek Yüksekokulu; \\ Sakarya Üniversitesi, SBE, İslam Ekonomisi ve Finansı EABD Doktora Öğrencisi \\ omerkskn21@gmail.com, OrcID: 0000-0002-1939-2791

\section{Öğr. Gör. Yunus Emre AYTEKİN} \\ Sinop Üniversitesi, Boyabat Meslek Yüksekokulu; \\ Sakarya Üniversitesi, SBE, İslam Ekonomisi ve Finansı EABD Doktora Öğrencisi \\ yea61@ hotmail.com, OrcID: 0000-0001-5805-0850
}

\section{Öz}

Barter sistemi, Türkçe literatürdeki çalışmaların özellikle bazılarında hem bütünüyle tutarsız bir terminoloji kullanılarak hem de kendine özgü bazı yönleriyle doğrudan bağdaştırılamayacak çıkarımlarda bulunularak açıklanmıştır. Bu çalışmanın amacı, barter sistemi ile ilgili yapılmış bazı çalışmalardaki açıklamaları inceleyerek, sistemle doğrudan bağdaştırılamayacak noktaları tespit edip bu noktaları eleştirel bir bakış açısıyla değerlendirmek suretiyle teorik açıdan Türkçe literatüre katkı sağlamaktır. Bu bağlamda, çalışma kapsamında ilk önce barter sistemi, bütünüyle daha tutarlı olacağı düşünülen bir terminoloji kullanılarak açıklanmıştır. Daha sonra, barter sistemi ile ilgili yapılmış bazı çalışmalardaki açıklamalar incelenerek, sistemle doğrudan bağdaştırılamayacak noktalar tespit edilmeye çalışılmıştır. Son olarak, tespit edilen noktalar, bulgular başlığı altında kategorilere ayrılmış ve tek tek yorumlanmıştır. Çalışmanın sonucuna göre, incelemeye tabi tutulan açıklamalar, genel anlamda barter sisteminin kendine özgü hukuki mahiyeti ve kredilendirme ilkesiyle tam anlamıyla uyuşmamaktadır.

Anahtar Kelimeler: Barter Sistemi, Barter İşlemi, Genel Üyelik Sözleşmesi, Barter Sözleşmesi

JEL Sınıflandırmaları: A12, K0, M21 


\title{
Barter System: An Examination of Studies Conducted in the Turkish Literature
}

\begin{abstract}
The Barter system has been elucidated by applying inconsistent terminology and making inferences that cannot be directly reconciled with some of its unique aspects, particularly in some of the studies in the Turkish literature. The aim of this study is to contribute to the Turkish literature from a theoretical perspective by examining the explications in some studies on the barter system, identifying the points that cannot be directly associated with the system, and evaluating these points with a critical perspective. In this regard, within the scope of the study, firstly, the barter system is clarified using terminology that is considered to be more consistent. Then, by examining the explanations in some studies on the barter system, points that cannot be directly associated with the system were tried to be identified. Finally, the determined points were categorized in the results section and expounded one by one. According to the conclusion of the study, the explications that were examined do not entirely comply with the specific legal nature of the barter system and the principle of crediting in general.
\end{abstract}

Keywords: Barter System, Barter Transaction, General Membership Agreement, Barter Agreement

JEL Classification: A12, K0, M21

\section{Giriş}

Araştırmanın konusunu oluşturan ve bir sistemi anlatan "barter"in kelime anlamı takas $^{1}$ ve trampadır (Avery ve diğ., 1996). Trampa, eşit değerde olduğu kabul edilen iki malın karşılıklı ve eş zamanlı olarak değiştirilmesi işlemidir. Trampa işlemi yapmak, paranın icadından önce insanların ihtiyaç duydukları malları elde edebilmelerinin tek yolu olmuştur. Paranın icadından sonra önemini giderek yitirmeye başlayan trampa işlemi, günümüzde özellikle uluslararası ticarette ${ }^{2}$ yoğun bir şekilde yapılmaya devam etmektedir.

1 Takasın anlamı, iktisat ve hukuk terminolojisinde birbirinden farklıdır. Takas, iktisat terminolojisinde genellikle trampanın yerine malın malla değişimi anlamında, hukuk terminolojisinde ise iki tarafın karşılıklı ve özdeş borçlarının birbirini düşürmesi anlamında kullanılmaktadır. Bu çalışmada anlam karmaşası oluşmaması için malın malla değişimi "trampa", iki tarafın karşılıklı ve özdeş borçlarının birbirini düşürmesi ise "takas" olarak adlandırılmaktadır.

2 Günümüzde ABD'nin (Amerika Birleşik Devletleri) Rusya, İran ve Venezuela gibi büyük petrol kaynaklarına sahip olan ülkelere ekonomik ambargo uygulaması, hem ambargo 
Geçmişten günümüze yapılagelmiş trampa işleminin temel şartı "isteklerin çifte beraberliği”dir. Başka bir deyişle, trampa işleminin gerçekleştirilebilmesi için, ilk önce mal istekleri birbirine uyan iki tarafın bir araya gelmesi gerekmektedir. Daha sonra, değişime konu edilecek iki mal arasında değer eşitliği sağlanarak trampa işlemi gerçekleştirilmektedir. Böylelikle ihtiyaç fazlası bir mal, ihtiyaç duyulan diğer bir malla değiştirilmektedir.

Trampa işleminin hakim olduğu bir ekonomide bazı güçlüklerle karşılaşılacağı açıktır. Örneğin, böyle bir ekonomide mal istekleri birbirine uyan iki tarafın bir araya gelmesi uzun bir zaman alacaktır. Dolayısıyla çabuk bozulabilir nitelikteki bir mal, başka bir malla değiştirilemeden bozulacaktır. Ayrıca yeni mallar üretildikçe, bu malların mevcut mallar cinsinden değerlerini yansıtacak yeni fiyatların saptanması gerekli olacaktır. Bu durumda malların birbirlerine göre değerlerinin ne olduğu ile ilgili bilgi karmaşası oluşacaktır.

Trampa işleminin hakim olduğu bir ekonomide ticari organizasyonun da son derece güç olacağı açıktır. Çünkü böyle bir ekonomide yeni mallar üretildikçe, bu malların diğer mallarla değişimini sağlayacak yeni ticaret noktalarına ihtiyaç duyulacaktır. Şöyle ki, başlangıçta sadece A, B ve C gibi üç malın üretildiği varsayıldığında, A'nın B ve C ile ve B'nin de C ile değişsimini sağlayan üç ayrı ticaret noktası bulunacaktır. Yeni bir mal olarak D malının üretilmesi durumunda, bu malın A, $B$ ve $C$ ile değişimini sağlayacak üç yeni ticaret noktası gerekli olacaktır. Sonuç olarak, ekonomideki mal sayısı arttıkça, ticari organizasyon giderek karmaşık bir hal alacaktır (Paya, 2013: 17-18).

Barter sistemi, barter şirketi aracılığıyla bir araya gelen sistem üyesi birçok işletme arasında sadece malların değil, aynı zamanda hizmetlerin de değişiminin yapıldığı ve işleyişte değer ölçüsü olarak paranın ${ }^{3}$ kullanıldığı modern bir ticaret sistemidir. Sistem, esasen işletmelerin finansman ve ticaret faaliyetlerinde paraya olan bağımlılıklarını azaltmak için trampa işleminden esinlenerek geliştirilmiştir. $\mathrm{Bu}$ doğrultuda para, sistem içerisinde elde bulundurma ve kullanma gereği yönünden bir yana bırakılmıştır. Böylelikle işleyişte “ödeme yerine değişim” esas alınmıştır.

Barter sisteminde üyeler arasında yapılan mal ve/veya hizmet değişimleri, genellikle trampa işlemindeki iki taraflı değişimden farklı olarak çok taraflı bir değişim şeklinde gerçekleşmektedir. Yani barter işlemi ${ }^{4}$ yapan iki üye, genellikle karşılıklı ve eş

altındaki ülkeleri hem de ambargo altındaki ülkelerle ticari ilişkileri bulunan ülkeleri trampa işlemi yapmaya yöneltmektedir. Çünkü trampa işlemi yapmak, finansal işlemlere yönelik yaptırımlardan önemli bir çıkış yolu olarak kabul edilmektedir.

3 Barter sisteminde para, değişim aracı olarak kullanılmamakta ve sadece değer ölçütü işlevinden yararlanılarak mal ve/veya hizmetlerin üyeler arasındaki değişimini sağlamaktadır.

4 Barter sisteminde iki üye arasında yapılan, konusu mal ve/veya hizmetten oluşan ve iki üyeden genellikle sadece birini ihtiyaç duyduğu mal ve/veya hizmete kavuşturan işlem bu çalışmada "barter işlemi”" olarak adlandırılmaktadır. 
zamanlı bir değişim ilişkisi içerisine girmemektedir. Çünkü işleyişte her üyenin ihtiyaç duyduğu mal ve/veya hizmetin, barter işlemi yaptığı diğer üyeden elde edilebilme olasılığı oldukça düşük seviyededir. Sonuçta barter işlemi yapan iki üyeden genellikle sadece biri ihtiyaç duyduğu mal ve/veya hizmeti elde edebilmekte, diğerinin ihtiyaç duyduğu mal ve/veya hizmeti elde edebilmesi ise ihtiyacını karşılayabilecek başka bir üyeyle daha ileri bir tarihte bir araya gelmesine kadar ertelenmektedir.

Barter sistemi, trampa işlemi yapmanın güçlükleri karşısında büyük kolaylıklar getirmektedir. Örneğin, üyelerin arz-talep bilgileri, barter şirketi tarafindan sistemin ana unsuru olan online bilgi bankası platformuna kaydedilmektedir. Dolayısıyla üyelerin hangi mal ve/veya hizmetleri arz-talep ettikleri, bilgi bankasından ayrıntılı ve hızlı bir şekilde öğrenilebilmektedir. Ayrıca bilgi bankası, üyelerin arz-talep ettikleri mal ve/veya hizmetlerin nitelikleri, fiyatları ${ }^{5}$ ve miktarları ile ilgili bilgileri de içermektedir. $\mathrm{Bu}$ bilgiler, barter işlemlerine taraf olacak üyelerin herhangi bir belirsizlikle karşılaşmaları ihtimalini minimum düzeye indirmektedir. Diğer taraftan üyeler arasında yapılan barter işlemleri, barter şirketi tarafından etkin bir şekilde organize edilmektedir. Barter şirketinin etkin organizasyonu sayesinde ticari organizasyonda oluşabilecek karmaşıklıkların önüne geçilebilmektedir.

Barter sistemi, üyelerin arz-talep ettikleri mal ve/veya hizmetler için bir havuz ${ }^{6}$ işlevi görmektedir. Üyeler, sistemden (havuzdan) alacaklı olmak/sisteme (havuza) borçlanmak suretiyle kendi aralarında barter işlemleri yapmaktadırlar. Başka bir deyişle, barter işleminde üyelerden biri, bir diğer üyeye mal ve/veya hizmet sunduğunda, sunduğu mal ve/veya hizmetin değeri kadar sistemden alacaklı olmaktadır. Mal ve/veya hizmet elde eden diğer üye ise elde ettiği mal ve/veya hizmetin değeri kadar sisteme borçlanmaktadır (bkz. Şekil 1).

5 Barter sisteminde üyeler, barter işlemlerinde sunacakları mal ve/veya hizmetlerin fiyatlarını barter şirketine bildirmektedirler. Barter şirketi, kendisine bildirilen fiyatların piyasadaki fiyatlarla paralel olup olmadığını kontrol etmektedir. Eğer fiyatlarda paralellik yoksa, söz konusu işlemlerin yapılmasına onay verilmemektedir. Bu noktada barter şirketinin yaptığ 1 fiyat kontrol işlemi, hem sistemdeki üyelerin aldatılmasının önüne geçilmesi hem de sistemin sağlıklı bir şekilde işlemesi itibarıyla önemlidir.

6 Barter sisteminde üyelerin arz-talep ettikleri mal ve/veya hizmetlerin bilgi bankasında bir araya toplanmasıyla oluşan yapı bu çalışmada "havuz" olarak adlandırılmaktadır. 


\section{Şekil 1: Barter Sisteminde Çok Taraflı Değişim Esaslı İşleyiş}

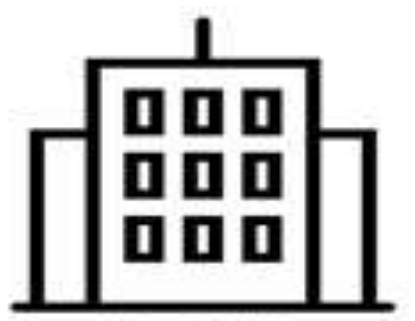

Barter Sirkets

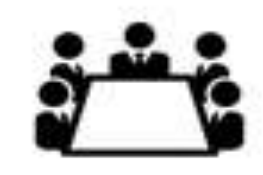

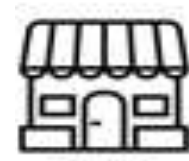

Dye B

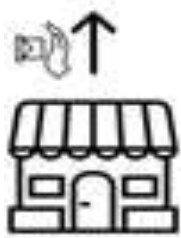

Oye A

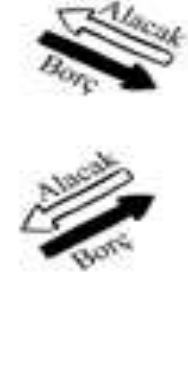

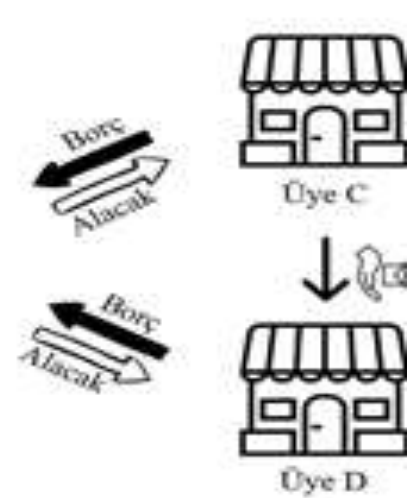

Oye D

Kaynak: Araştırmacılar tarafindan oluşturulmuştur.

Barter sistemi, üyeler tarafindan alternatif bir finansman ve ticaret yöntemi olarak değerlendirilmektedir. Şöyle ki, barter işleminde mal ve/veya hizmet elde eden üye, sisteme olan borcunu 12 ay içinde üyelere mal ve/veya hizmet sunarak veya bu süre sonunda herhangi bir faiz maliyetine katlanmaksızın barter şirketine nakit olarak ödeyebilmektedir. Mal ve/veya hizmet sunan üye ise gereğinden fazla olan stoklarını eritebilmekte, atıl kapasitesini değerlendirebilmekte ve sistemden alacağını 12 ay içinde üyelerden mal ve/veya hizmet elde ederek tahsil edebilmektedir. Böylelikle sistem, barter işleminde mal ve/veya hizmet elde eden üye için alternatif bir finansman yöntemi, mal ve/veya hizmet sunan üye için ise alternatif bir ticaret yöntemi olarak işlev görmektedir.

Türkçe literatür incelendiğinde, barter sisteminin açıklandığı birçok çalışmayla karşılaşılmaktadır. Ancak söz konusu çalışmaların özellikle bazılarında yapılan 
açıklamalarda sistemle doğrudan bağdaştırılamayacak noktalar olduğu göze çarpmaktadır. Dolayısıyla bu çalışmanın konusu, ilgili noktaları tespit etme ve tek tek yorumlama üzerine odaklanmaktadır.

\section{Araştırmanın Amacı}

$\mathrm{Bu}$ çalışma, barter sistemi ile ilgili yapılmış bazı çalışmalardaki açıklamaları inceleyerek, sistemle doğrudan bağdaştırılamayacak noktaları tespit edip bu noktaları eleştirel bir bakış açısıyla değerlendirmek suretiyle teorik açıdan Türkçe literatüre katkı sağlamayı amaçlamaktadır.

\section{Araştırmanın Önemi}

Türkiye'de günümüze kadar barter sistemi ile ilgili farklı türlerde (tez, makale ve kitap) birçok çalışma yapılmıştır. Söz konusu çalışmalara ayrı ayrı ve literatür özeti olarak Tablo 1'de yer verilmiştir. Tablo 1 incelendiğinde, bu çalışmanın ele aldığı konu başlığı ile ilgili günümüze kadar yapılmış herhangi bir çalışma olmadığı görülmektedir. Dolayısıyla bu çalışma, ele aldığı konu itibarıyla Türkçe literatürdeki ilk çalışma olacağından önem arz etmektedir.

Tablo 1: Türkiye’de Barter Sistemi ile ilgili Yapılmış Çalışmalara İlişkin Literatür Özeti

\begin{tabular}{|c|c|c|c|c|}
\hline \multicolumn{5}{|c|}{ TEZ ÇALIŞMALARI } \\
\hline YAZARLAR & YIL & $\begin{array}{c}\text { ARAŞTIRMA } \\
\text { ALANI }\end{array}$ & ARAŞTIRMA KONUSU & ARAŞTIRMA BULGULARI \\
\hline Şenol & 1999 & Barter sistemi & $\begin{array}{l}\text { Barter işlemlerinin } \\
\text { muhasebeleştirilmesi. }\end{array}$ & $\begin{array}{l}\text { Çalışmada barter sistemi ile ilgili teorik } \\
\text { açıklamalar ve en temel muhasebe kayıtları } \\
\text { yapılmıştır. }\end{array}$ \\
\hline Güler & 2004 & Barter sistemi & $\begin{array}{l}\text { Barter sisteminin Türkiye'de } \\
\text { kullanımının sektörler } \\
\text { açısından değerlendirilmesi ve } \\
\text { barter işlemlerinin } \\
\text { muhasebeleştirilmesi. }\end{array}$ & $\begin{array}{llll}\text { Çalışmada barter sisteminin } & \text { çeşitli } \\
\text { sektörlerde } & \text { kullanımı ile ilgili } & \text { teorik } \\
\text { açıklamalar ve örnekler üzerinden } & \text { barter } \\
\text { işlemlerinin muhasebesi yapılmıştır. } & \end{array}$ \\
\hline Tekşen & 2006 & $\begin{array}{l}\text { Barter sistemini } \\
\text { kullanan } 207 \\
\text { işletme }\end{array}$ & $\begin{array}{l}\text { İşletmelerin barter sistemine } \\
\text { bakış açıları ile ilgili bilgilerin } \\
\text { değerlendirilmesi. }\end{array}$ & $\begin{array}{l}\text { Barter şirketlerinin barter sisteminin işleyişi } \\
\text { hakkında işletmelere bilgi vermedikleri ve } \\
\text { barter sisteminin teoride anlatılan } \\
\text { faydalarının pratikte işletmeler nezdinde } \\
\text { yeterince görülmediği tespit edilmiştir. }\end{array}$ \\
\hline Dorcpalam & 2007 & Barter sistemi & $\begin{array}{c}\text { Barter işlemlerinin } \\
\text { muhasebeleştirilmesi. }\end{array}$ & $\begin{array}{l}\text { Çalışmada barter sistemi ile ilgili teorik } \\
\text { açıklamalar ve bir uygulama örneği } \\
\text { üzerinden barter işlemlerinin muhasebesi } \\
\text { yapılmıştır. }\end{array}$ \\
\hline Oduncuoğlu & 2007 & $\begin{array}{l}\text { Konaklama } \\
\text { işletmeleri }\end{array}$ & $\begin{array}{l}\text { Barter sisteminin konaklama } \\
\text { işletmelerindeki pazarlama } \\
\text { fonksiyonuna etkisi. }\end{array}$ & $\begin{array}{l}\text { Barter sistemi ve konaklama işletmelerinin } \\
\text { pazarlama fonksiyonları arasında anlamlı ve } \\
\text { pozitif yönlü bir ilişki olduğu tespit }\end{array}$ \\
\hline
\end{tabular}


Barter System: An Examination of Studies

KESKIN \& AYTEKIN Conducted in the Turkish Literature

\begin{tabular}{|c|c|c|c|c|}
\hline & & & & edilmiştir. \\
\hline Koçdoğan & 2008 & Barter sistemi & $\begin{array}{l}\text { Barter sisteminin İslam Borçlar } \\
\text { Hukuku'ndaki yeri. }\end{array}$ & $\begin{array}{l}\text { Fikıh kitaplarında yer almayan barter } \\
\text { sisteminin uygulamada birçok yönüyle İslam } \\
\text { Borçlar Hukuku'nun ortaya koyduğu } \\
\text { hükümlere uygunluk arz ettiği tespit } \\
\text { edilmiştir. }\end{array}$ \\
\hline Bayrav & 2009 & Barter sistemi & Barter sisteminin incelenmesi. & $\begin{array}{l}\text { Çalışmada sadece barter sistemi ile ilgili } \\
\text { teorik açıklamalar yapılmıştır. }\end{array}$ \\
\hline Hacıcaferoğlu & 2010 & Spor sektörü & $\begin{array}{c}\text { Barter sisteminin spor } \\
\text { kulüplerinde kullanılabilirliği. }\end{array}$ & $\begin{array}{l}\text { Spor kulübü yöneticileriyle yapılan } \\
\text { mülakatlar sonucunda barter sisteminin } \\
\text { özellikle spor kulüplerinin yaşamış oldukları } \\
\text { ekonomik kriz dönemlerinde alternatif bir } \\
\text { finansman yöntemi olarak kullanılabileceği } \\
\text { tespit edilmiştir. }\end{array}$ \\
\hline Uzun & 2010 & $\begin{array}{l}\text { Küçük ve orta } \\
\text { boy işletmeler }\end{array}$ & $\begin{array}{l}\text { İşletmelerin barter sistemini } \\
\text { kullanım amaçları. }\end{array}$ & $\begin{array}{l}\text { İşletmelerin \%50'sinin nakit sıkıntısı } \\
\text { çekmeden ticaret yapmak, \%18,3'ünün atıl } \\
\text { kapasitelerini değerlendirmek, \%13,6'sının } \\
\text { stoklarını eritmek ve \%13,6'sının da işletme } \\
\text { giderlerini azaltmak için barter sistemini } \\
\text { kullandıkları tespit edilmiştir. }\end{array}$ \\
\hline Yolaçan & 2010 & $\begin{array}{l}\text { Dedeman } \\
\text { Turizm } \\
\text { Yatırımları } \\
\text { A.Ş. (Anonim } \\
\quad \text { Şirketi) }\end{array}$ & $\begin{array}{l}\text { Barter sisteminin Dedeman } \\
\text { Turizm Yatırımları A.Ş.'ye } \\
\text { etkileri. }\end{array}$ & $\begin{array}{l}\text { Barter sistemini kullanan şirketin nakit } \\
\text { tasarrufu sağladığ } 1 \text { ve kasa hesabını } \\
\text { artırdığ1 tespit edilmiştir. }\end{array}$ \\
\hline Özkoçak & 2011 & $\begin{array}{l}\text { Eskişehir } \\
\text { Organize } \\
\text { Sanayi } \\
\text { Bölgesi'ndeki } \\
\text { işletmeler }\end{array}$ & $\begin{array}{l}\text { Barter sisteminin } \\
\text { Eskişehir'de } \\
\text { kullanılmamasında nelerin } \\
\text { etkin olduğunun tespiti. }\end{array}$ & $\begin{array}{l}\text { İşletmelerin barter sistemini kullanma } \\
\text { yönünde istekli oldukları ancak barter } \\
\text { şirketleri tarafından bu işletmelere } \\
\text { gereken ilgi gösterilmediği için sistemin } \\
\text { Eskişehir'de kullanılmadığ } \\
\text { edilmiştir. }\end{array}$ \\
\hline Dalgıç & 2011 & Barter sistemi & $\begin{array}{l}\text { Barter sisteminin } \\
\text { incelenmesi. }\end{array}$ & $\begin{array}{l}\text { Çalışmada sadece barter sistemi ile ilgili } \\
\text { teorik açıklamalar yapılmıştır. }\end{array}$ \\
\hline Uyan & 2013 & $\begin{array}{l}\text { Barter sistemini } \\
\text { kullanan } 4 \\
\text { işletme }\end{array}$ & $\begin{array}{l}\text { Barter sistemini kullanmanın } \\
\text { işletmelere faydaları. }\end{array}$ & $\begin{array}{l}\text { Barter sistemini kullanan işletmelerin } \\
\text { karda ve üretimde artış sağladıkları, yeni } \\
\text { müşteriler kazandıkları ve finansman } \\
\text { maliyetlerini azalttıkları tespit edilmiştir. }\end{array}$ \\
\hline Camız & 2015 & $\begin{array}{c}\text { Barter } \\
\text { sözleşmesi }\end{array}$ & $\begin{array}{c}\text { Barter sözleşmesi ve bu } \\
\text { sözleşmeden doğan } \\
\text { uyuşmazlıklara uygulanacak } \\
\text { hukuk. }\end{array}$ & $\begin{array}{l}\text { Çalışmada barter sözleşmesinin hukuki } \\
\text { niteliği ve milletlerarası özel hukuk } \\
\text { uyarınca barter sözleşmesine hangi } \\
\text { hukukun uygulanacağı ile ilgili teorik } \\
\text { açıklamalar yapılmıştır. }\end{array}$ \\
\hline Aşar & 2016 & $\begin{array}{l}\text { Barter sistemini } \\
\text { kullanan } 100 \\
\text { işletme }\end{array}$ & $\begin{array}{l}\text { İşletmelerin barter sistemini } \\
\text { kullanım amaçları ve } \\
\text { uygulamada karşılaşılan } \\
\text { sorunlar. }\end{array}$ & $\begin{array}{l}\text { İşletmelerin portföy yaratmak, tanıtım } \\
\text { yapmak, borçları uzun vadelere bölmek ve } \\
\text { kısa zamanda piyasaya girmek gibi çeşitli } \\
\text { amaçlarla barter sistemini kullandıkları tespit } \\
\text { edilmiştir. Ayrıca sistemde karşılaşılan } \\
\text { birçok sorunun hukuki düzenleme } \\
\text { eksikliğinden değil, sistem hakkındaki düşük }\end{array}$ \\
\hline
\end{tabular}




\begin{tabular}{|c|c|c|c|c|}
\hline & & & & $\begin{array}{l}\text { bilgi seviyesinden ve sorun çözme } \\
\text { mekanizmalarının } \\
\text { kaynaklandığı ifade edilmiştir. }\end{array}$ \\
\hline Saka & 2017 & $\begin{array}{c}\text { Barter } \\
\text { sistemine özgü } \\
\text { sözleşmeler }\end{array}$ & $\begin{array}{l}\text { Barter üyelik sözleşmesinin ve } \\
\text { barter sözleşmesinin Türk } \\
\text { hukuk mevzuatındaki yeri. }\end{array}$ & $\begin{array}{l}\text { Çalışmada barter üyelik sözleşmesi ve barter } \\
\text { sözleşmesinin hukuki nitelikleri ve bu } \\
\text { sözleşmelerin taraflara getirdiği hak ve } \\
\text { yükümlülükler ile ilgili teorik açıklamalar } \\
\text { yapılmıştır. }\end{array}$ \\
\hline Yilmaz & 2018 & Barter sistemi & $\begin{array}{l}\text { Barter işlemlerinin } \\
\text { muhasebeleştirilmesi. }\end{array}$ & $\begin{array}{l}\text { Çalışmada barter sistemi ile ilgili teorik } \\
\text { açılamalar ve örnek bir barter işleminin } \\
\text { muhasebesi yapılmıştır. }\end{array}$ \\
\hline Sarak & 2019 & Barter sistemi & $\begin{array}{l}\text { Finans sektöründe barter } \\
\text { sisteminin uygulanabilirliği ve } \\
\text { vergisel boyutu. }\end{array}$ & $\begin{array}{l}\text { Çalışmada sadece barter sistemi ile ilgili } \\
\text { teorik açıklamalar yapılmıştır. }\end{array}$ \\
\hline \multicolumn{5}{|c|}{ MAKALE ÇALIŞMALARI } \\
\hline $\begin{array}{l}\text { YAZAR(LA } \\
\mathbf{R})\end{array}$ & YIL & $\begin{array}{l}\text { ARAŞTIRMA } \\
\text { ALANI }\end{array}$ & ARAŞTIRMA KONUSU & ARAŞTIRMA BULGULARI \\
\hline Erkan & $\begin{array}{c}2000 \\
b\end{array}$ & Barter sistemi & $\begin{array}{l}\text { Barter sisteminin diğer } \\
\text { finansman teknikleriyle } \\
\text { karşılaştırılması. }\end{array}$ & $\begin{array}{l}\text { Çalışmada alternatif bir finansman aracı } \\
\text { olan barter sisteminin diğer finansman } \\
\text { teknikleriyle karşılaştırması yapılmıştır. }\end{array}$ \\
\hline Özkan & 2002 & Barter sistemi & $\begin{array}{l}\text { Barter işlemlerinin } \\
\text { muhasebeleştirilmesi. }\end{array}$ & $\begin{array}{l}\text { Çalışmada barter sistemi ile ilgili teorik } \\
\text { açılamalar ve örnek bir barter işleminin } \\
\text { muhasebesi yapılmıştır. }\end{array}$ \\
\hline Öz ve Dursun & 2005 & $\begin{array}{l}\text { Barter sistemini } \\
\text { kullanan } 171 \\
\text { işletme }\end{array}$ & $\begin{array}{l}\text { İşletmelerin barter sistemini } \\
\text { kullanım amaçları. }\end{array}$ & $\begin{array}{l}\text { İşletmelerin büyük bir çoğunluğunun } \\
\text { finansman ihtiyaçlarını azaltmak ve atı } \\
\text { kapasitelerini değerlendirmek için barter } \\
\text { sistemini kullandıkları tespit edilmiştir. }\end{array}$ \\
\hline Yardımcıoğlu & 2006 & Barter sistemi & $\begin{array}{l}\text { Barter işlemlerinin } \\
\text { muhasebeleştirilmesi. }\end{array}$ & $\begin{array}{l}\text { Çalışmada barter sistemi ile ilgili teorik } \\
\text { açılamalar ve örnek bir barter işleminin } \\
\text { muhasebesi yapılmıştır. }\end{array}$ \\
\hline $\begin{array}{l}\text { Demir ve } \\
\text { Ürgüp }\end{array}$ & 2014 & $\begin{array}{l}\text { Bist’te (Borsa } \\
\text { İstanbul) işlem } \\
\text { gören iki } \\
\text { işletme }\end{array}$ & $\begin{array}{l}\text { Barter sisteminin teoride } \\
\text { anlatılan faydalarının } \\
\text { pratikteki sonuçları. }\end{array}$ & $\begin{array}{l}\text { Barter sistemini kullanan iki işletmenin } \\
\text { sistemden yeterince fayda sağlayamadığ } \\
\text { ve dolayısıyla sistemin faydalarının daha } \\
\text { çok teoride kaldığ } 1 \text { tespit edilmiştir. }\end{array}$ \\
\hline Özeroğlu & 2014 & Barter sistemi & $\begin{array}{l}\text { Barter sistemi ve Türk finans } \\
\text { sektöründe uygulanabilirliği. }\end{array}$ & $\begin{array}{l}\text { Çalışmada sadece barter sistemi ile ilgili } \\
\text { teorik açıklamalar yapılmıştır. }\end{array}$ \\
\hline Karyağ $d_{1}$ & 2014 & $\begin{array}{l}\text { Muş ilinde } \\
\text { tarım alet ve } \\
\text { üretimi yapan } \\
\text { işletmeler }\end{array}$ & $\begin{array}{l}\text { İşletmelerin kullandıkları } \\
\text { finansman yöntemleri. }\end{array}$ & $\begin{array}{l}\text { İşletmelerin kullandıkları finansman } \\
\text { yöntemlerinin \%6,7'sinin barter sistemi } \\
\text { ve leasingden oluştuğu tespit edilmiştir. }\end{array}$ \\
\hline $\begin{array}{l}\text { Kırlığlu ve } \\
\text { Bağdat }\end{array}$ & 2016 & Barter sistemi & $\begin{array}{l}\text { Barter işlemlerinin } \\
\text { muhasebeleştirilmesi. }\end{array}$ & $\begin{array}{l}\text { Çalışmada barter sistemi ile ilgili teorik } \\
\text { açılamalar ve bir örnek üzerinden barter } \\
\text { şirketinin en temel muhasebe kayıtları } \\
\text { yapılmıştır. }\end{array}$ \\
\hline $\begin{array}{l}\text { Mert ve } \\
\text { Dukan }\end{array}$ & 2017 & Barter sistemi & $\begin{array}{l}\text { Barter işlemlerinin } \\
\text { uluslararası muhasebe }\end{array}$ & $\begin{array}{l}\text { Çalışmada barter sistemi ile ilgili teorik } \\
\text { açılklamalar ve örnekler üzerinden barter }\end{array}$ \\
\hline
\end{tabular}


Barter System: An Examination of Studies

KESKIN \& AYTEKIN Conducted in the Turkish Literature

\begin{tabular}{|c|c|c|c|c|}
\hline & & & $\begin{array}{l}\text { standartlarına göre } \\
\text { muhasebeleştirilmesi. }\end{array}$ & işlemlerinin muhasebesi yapılmıştır. \\
\hline Güdelci & 2020 & Barter sistemi & $\begin{array}{c}\text { Barter işlemlerinin BOBİ } \\
\text { FRS (Büyük ve Orta Boy } \\
\text { İşletmeler için Finansal } \\
\text { Raporlama Standardı) } \\
\text { kapsamında } \\
\text { muhasebeleştirilmesi. }\end{array}$ & $\begin{array}{l}\text { Çalışmada barter sistemi ile ilgili teorik } \\
\text { açılamalar ve örnekler üzerinden barter } \\
\text { işlemlerinin muhasebesi yapılmıştır. }\end{array}$ \\
\hline \multicolumn{5}{|c|}{ KITAP ÇALIŞMALARI } \\
\hline \multicolumn{3}{|c|}{ YAZAR(LAR) } & YIL & ÇALIŞMA \\
\hline \multicolumn{3}{|c|}{ Gürsoy } & 1999 & $\begin{array}{l}\text { Barter El Kitabi-Dünyada ve Türkiye'de } \\
\text { Barter (Takas) Ticareti }\end{array}$ \\
\hline \multicolumn{3}{|c|}{ Arzova } & 2000 & $\begin{array}{l}\text { Barter İşlemleri-İşleyişi, Hukuki Yönü ve } \\
\text { Muhasebeleştirilmesi }\end{array}$ \\
\hline \multicolumn{3}{|c|}{ Keskin } & 2004 & Barter Sözleşmesi \\
\hline \multicolumn{3}{|c|}{ Şimşek } & 2004 & Parasız Ticaret Barter \\
\hline \multicolumn{3}{|c|}{ Belen } & 2007 & Barter Sistemi, Hukuki Yapısı ve İşleyişi \\
\hline \multicolumn{3}{|c|}{ Toroslu } & 2010 & Barter İşlemleri ve Muhasebesi \\
\hline \multicolumn{3}{|c|}{ Öz ve Güler } & 2011 & Barter Sistemi ve Vergilendirme \\
\hline
\end{tabular}

Kaynak: Araştırmacılar tarafindan oluşturulmuştur.

\section{Kavramsal Çerçeve}

Çalışmanın bu bölümünde sırasıyla barter sisteminin gelişimi, barter sistemi ile ilgili terimler ve barter sisteminin işleyiş şekli açıklığa kavuşturulmaktadır.

\subsection{Barter Sisteminin Gelişimi}

Trampa, eşit değerde olduğu kabul edilen iki malın birbiriyle eş zamanlı olarak değiştirilmesi işlemidir. İnsanlar, paranın icadından önce ihtiyaç duydukları malları sadece trampa işlemi yaparak elde edebilmişlerdir. Ancak para icat edilip tedavülde ağırlık kazanmaya başladıktan sonra trampa işlemi yapmanın sürdürülebilir olmadığı fark edilmiştir. Çünkü paranın değişim aracı olma işlevi, trampa işlemindeki "isteklerin çifte beraberliği”" şartına büyük bir alternatif teşkil etmiştir. Artık insanlar, mal olarak ödeme almaktan ziyade, para olarak ödeme almaya daha istekli hale gelmişlerdir (Tucker, 2010: 648). Ayrıca para, malların değerlerinin saptanmasında büyük bir bilgi tasarrufu sağlamıştır. Para sayesinde tek bir mal hesap birimi olarak kullanılmış ve diğer bütün malların değerleri bu mal cinsinden saptanmıştır (Paya, 2013: 18). Sonuç olarak, trampa işlemi, önemini giderek yitirmeye başlamış ve yerini satış işlemine bırakmıştır (Gürsoy, 1999: 3).

Satış, bir malın parayla değiştirilmesi işlemidir (Belen, 2007: 127). Satış işlemi, tarihsel gelişim süreci içinde trampa işleminden türemiştir ve dogmatik açıdan trampa 
işleminin altında yer almaktadır. Şöyle ki, satış işleminin temel unsuru olan para da hukuken bir maldır. Dolayısıyla satış işleminde de son tahlilde malın malla değişimi yapılmaktadır. Aralarında her ne kadar böyle bir ilişki bulunsa da trampa işlemi, paranın ticarete hakim olmasıyla satış işleminin ikincil türevi halini almıştır (Serozan, 2012: 6).

Para, bir yandan ticarete büyük bir hız kazandırmışken diğer yandan faiz olgusunu ortaya çıarıp ekonomik sistemde maliyetleri artırıcı yönde bir etki yaratmıştır. Faizin bu etkisi, ekonomik krizleri tetikleyici bir rol oynamıştır. Örneğin, 1929 Dünya Ekonomik Krizi’nde paranın maliyeti artmış ve ülkeler döviz kıtlığı yaşamışlardır (Arzova, 2000: 3). O yıllarda yaşanan döviz kıtlığı sonucunda paraya olan güven azalmış ve trampa işlemi ülkeler tarafından yeniden yapılmaya başlanmıştır. Özellikle Almanya, Avrupa ve Latin Amerika ülkeleriyle trampa işlemi yaparak, ihtiyaç duyduğu gıda ürünlerini ve hammaddeleri karşılamıştır (Sürmen ve Kaya, 2001: 131).

1929 Dünya Ekonomik Krizi'nde arz talepten fazla olduğu için işletmelerin stoklarında da artış yaşanmıştır. Stoklarını nakde çeviremeyen işletmeler, büyük ekonomik güçlüklerle karşılaşmışlardır. Alternatif çözüm arayışları sonucunda birçok ülkede trampa işlemi deneyiminden yola çıkılarak geliştirilen barter sistemi uygulanmaya başlanmıştır. Böylelikle trampa işlemi paranın icat edildiği zamana kadar ticaret yapmanın tek yolu olmuşken, barter sistemi ise paranın elde olmadığı veya çok pahalı olduğu zamanlarda ticaret yapmanın alternatif bir yolu olmuştur (Belen, 2007: 11-13).

Barter sistemi, sisteme üye olan işletmelerin barter şirketi aracılığıyla barter işlemleri yaptıkları modern bir ticaret sistemidir. İlk önce İsviçre'de geliştirilen ve 1934 yılında uygulanmaya başlanan sistem, daha sonra ABD'de, Avrupa ülkeleri genelinde ve Türkiye'de (1990'lı yıllar) yaygınlık kazanmıştır (Koç, 2008: 32). Sistem, özellikle stokların eritilmesinde ve atıl kapasitenin değerlendirilmesinde avantaj sağladığ için dünya genelinde birçok işletme tarafından kullanılmıştır (Yardımcıoğlu, 2006: 117). Sistemin kullanımı, bilgisayar teknolojisinde yaşanan hızlı gelişmelerin etkisiyle giderek yaygınlaşmıştır ("Referans Barter", t.y.). Bilgisayar teknolojisi sayesinde sistemde arz-taleplerin bir araya getirildiği online bilgi bankası platformu ortaya çıkmıştır. Bilgi bankası, sistemi kullanan işletmelerin derinlemesine bir piyasa araştırması yapılabilmelerine firsat sağlamıştır (Gürsoy, 1999: 10-11).

Barter sistemi, üyelerin mal ve/veya hizmet taleplerinin karşılanması esasına göre işlemekte ve bu talepleri karşılayabilecek işletmelerin sisteme davet edilmeleriyle büyümektedir (Şimşek, 2004: 28-29). Sistemin kalitesi, üyelerin sayısıyla doğru orantılıdır. Başka bir deyişle, üyelerin sayısı arttıkça, sistemin kalitesi de artmaktadır. Çünkü üyelerin sayısının artması, sistem içerisindeki mal ve hizmet çeşidinin de artması anlamına gelmektedir (Arzova, 2000: 3).

Dünya genelinde faaliyet gösteren barter şirketlerinin sayısının 750'den fazla olduğu tahmin edilmektedir. $\mathrm{Bu}$ şirketlerin büyük bir kısmı, ABD'de faaliyet 
göstermektedir (Boonstra ve diğ., 2013: 14). Ayrıca barter ticareti, merkezi ABD'de bulunan ve 1979 yılında kurulan Dünya Barter Birliği (IRTA) tarafından yönlendirilmektedir. IRTA, barter ticareti ile ilgili araştırmalar ve yönlendirmeler yapmakta, veritabanı hizmeti ve teknik danışmanlık hizmetleri sunmakta ve uluslararası ticaret bağlantıları sağlamaktadır. Günümüzde IRTA, çoğunluğu gelişmiş ve gelişmekte olan birçok ülke tarafından temsil edilen bir kuruluş konumundadır ("TÜRK BARTER", t.y.).

Dünya genelinde barter şirketlerinin organize ettikleri barter işlemlerinin hacimleri bu şirketler tarafından genellikle bildirilmediği için yapılan işlemlerin yıllık hacmi net olarak bilinmemektedir. Bununla birlikte IRTA, dünya genelinde 400 binden fazla işletme tarafından barter işlemleri yapıldığını ve yapılan işlemlerin yıllık hacminin yaklaşık 12-14 milyar \$ arasında olduğunu tahmin etmektedir. Barter ticaretinin son otuz beş yılda hızla büyümesi, birebir ticaretten üçüncü tarafla ticarete geçilmesinin ve ticaret firsatlarını en üst düzeye çıkarmak için gelişmiş internet tabanlı yazılımların geliştirilmesinin bir sonucu olarak görülmektedir ("IRTA", 2020).

\subsection{Barter Sistemi ile ilgili Terimler}

Barter sisteminde yaygın bir şekilde kullanılan ve sistemin yapısını oluşturan birçok terim bulunmaktadır. Söz konusu terimler, Tablo 2'de kısaca açıklanmaktadır.

\section{Tablo 2: Barter Sisteminde Yaygın Bir Şekilde Kullanılan Terimler}

Barter Şirketi: Barter sisteminin işleyiş ilkelerini belirleyen, sisteme üyelik başvurusunda bulunan işletmenin üyelik işlemlerini yürüten ve sistemdeki mal ve/veya hizmetlerin değişimini organize eden aracı kuruluştur. Barter şirketi, üyelik başvurusunun değerlendirilmesi sürecinde, başvuruda bulunan işletmenin piyasa kredibilitesini ve faaliyet gösterdiği sektörü dikkate almaktadır (Şimşek, 2004: 69$70)$.

Üye: Genel Üyelik Sözleşme’sini imzalayarak barter sistemine dahil olan işletmedir.

Genel Üyelik Sözleşmesi: Barter şirketi ve barter sistemine üyelik başvurusu kabul edilen işletme arasında yapılan, üyeye sistemde barter işlemi yapabilme hakkı sağlayan, üyenin cari hesabının tutulmasında barter şirketini yetkilendiren ve hem barter şirketinin hem de üyenin haklarını ve yükümlülüklerini düzenleyen sözleşmedir (Koç, 2008: 31).

Barter Sözleşmesi: İki üyenin barter işlemi esnasında yaptığı, ödemenin para yerine mal ve/veya hizmetle yapılmasının kararlaştırıldığı ve geçerliliği barter şirketinin onayına bağlı sözleşmedir (Saka, 2017: 77). Barter işlemi, Barter Sözleşmesi adı altında iki taraflı bir sözleşme gibi gerçekleştirilmektedir. 
Bilgi Bankası: Üyenin arz-talep bilgilerinin kaydedildiği online platformdur. Ayrıca bilgi bankası, arz-talep edilen mal ve/veya hizmetlerin nitelikleri, fiyatları ve miktarları ile ilgili bilgileri de içermektedir.

Cari Hesap: Genel Üyelik Sözleşmesi'ni imzaladıktan sonra barter şirketine yıllık üyelik aidatını ödeyen üye için açılan hesaptır. Bu hesapta üyenin yaptığı barter işlemlerinin değerleri, alacak-borç bakiyesi ve kredi limiti kayıt altına alınmaktadır.

Barter Çeki: Barter işleminde mal ve/veya hizmet elde eden üye tarafindan üç nüsha halinde düzenlenen kıymetli evraktır. Bu evrak, sadece barter sistemi içerisinde geçerli olmakta ve barter işleminde hem ispat hem de ödeme aracı olarak kullanılmaktadır.

Barter Doları: Barter sisteminde özel olarak üretilen ve üyenin cari hesabı tutulurken kullanılan para birimidir (Şimşek, 2004: 40). Para birimi niteliğindeki barter doları, değişim aracı olarak değil, muhasebesel kayıt aracı olarak (değer ölçüsü olarak) işlev görmektedir (Toroslu, 2010: 3). Barter dolarının değeri, genellikle ABD doları veya Euro gibi yabanc1 para birimlerine endekslidir.

Barter Brokerı: Barter şirketi tarafindan üye için tayin edilen ve yapacağı barter işlemlerinde üyeye rehberlik eden kişidir.

Kredi Limiti: Barter şirketi tarafından üye için belirlenen, üyenin barter işlemlerinde mal ve/veya hizmet elde ederken kullanabileceği maksimum kredi miktarıdır. Kredi miktarının ölçütü, üyenin daha önce barter işlemlerinde sunduğu mal ve/veya hizmetlerin değeridir. Daha önce barter işlemlerinde mal ve/veya hizmet sunmamış üye, barter şirketine teminat verebilir ve böylelikle kullanabileceği bir kredi limitine sahip olabilir (Tekşen, 2006: 10). Bu limit, verilen teminatın değerinin \%50'si kadar olmaktadır (Şimşek, 2004: 104).

Teminat: Kredi limitine sahip olmak isteyen üye tarafından barter şirketine verilen gayrimenkul ipoteği ve banka teminat mektubu gibi enstrümanlardır ("GLOBAL BARTER", t.y.-a).

Barter İşlemi Onay Kodu: Barter şirketinin, barter işleminde mal ve/veya hizmet elde etmek isteyen üyenin kredi limitini kontrol etmesi sonucunda işlem için verdiği onay kodudur. Bu kod, üyenin kredi limitinin barter işlemi yapmaya uygun olduğunu göstermektedir.

Arz Formu ve Arz Listesi: Arz formu, üyenin barter işlemlerinde sunmak istediği mal ve/veya hizmetler ile ilgili bilgilerin yer aldığ 1 formdur. Arz listesi ise üyenin arz formunda yer alan bilgilerin barter şirketi tarafından diğer üyelerin de görebileceği şekilde bilgi bankasında liste halinde yayınlanmasıdır ("REFERANS BARTER", t.y.). 
Talep Formu ve Talep Listesi: Talep formu, üyenin barter işlemlerinde elde etmek istediği mal ve/veya hizmetler ile ilgili bilgilerin yer aldığ formdur. Talep listesi ise üyenin talep formunda yer alan bilgilerin barter şirketi tarafından diğer üyelerin de görebileceği şekilde bilgi bankasında liste halinde yayınlanmasıdır ("REFERANS BARTER", t.y.).

Barter İşlem Komisyonu: Barter şirketinin, sunduğu danışmanlık ve aracılık hizmetleri karşılığında barter işlemi yapan iki üyeden nakit olarak aldığı oransal bir değerdir. İşlem başına alınan komisyon, yapılan işlemin değerinin genellikle \% $\%$ 'i kadardır (Arzova, 2000: 3).

Yılık Üyelik Aidatı: Barter şirketinin, barter sisteminin kurulması ve sağlıklı bir şekilde işlemesi için yürüttüğü faaliyetler karşılığında tüm üyelerden yıllık olarak aldığı nakit değerdir.

Kaynak: Araştırmacılar tarafindan oluşturulmuştur.

\subsection{Barter Sisteminin İşleyiş Şekli}

Barter sistemi, üyelerin ihtiyaç duydukları mal ve/veya hizmetlerin çok taraflı değişim esasıyla karşılanmasına hizmet eden modern bir ticaret sistemidir. Sistemdeki üyelerin temel amacı, barter işlemleri yaparak ihtiyaç duydukları mal ve/veya hizmetleri elde etmektedir. Bu amaca genellikle karşılıklılık ve eş zamanlılıktan bağımsız bir şekilde ulaşllabilmektedir. Çünkü işleyişte her üyenin ihtiyaç duyduğu mal ve/veya hizmetin, barter işlemi yaptığ1 diğer üyeden elde edilebilme olasılığı oldukça düşük seviyededir.

İşleyişte barter işlemi yapmak için bir araya gelen iki üyeden genellikle sadece biri ihtiyaç duyduğu mal ve/veya hizmeti elde edebilmekte, diğerinin ihtiyaç duyduğu mal ve/veya hizmeti elde edebilmesi ise ihtiyacını karşılayabilecek başka bir üyeyle daha ileri bir tarihte bir araya gelmesine kadar ertelenmektedir. Bununla birlikte barter işlemlerindeki karşılıklılık, barter şirketi tarafından işlem yapan üyelerin cari hesaplarında tutulan alacak-borç kayıtlarıyla sağlanmaktadır. Barter sisteminde üyeler için çok çeşitli arz-talep alternatifleri bulunmaktadır. Barter şirketi, bu çok çeşitli arztalepleri düzenlemektedir.

Barter işleminde mal ve/veya hizmet sunan üyenin alacağının konusu, kural olarak para değil, diğer üyeler tarafından barter sisteminde arz edilen ve alacağını karşılayacak değerde olan herhangi bir mal ve/veya hizmettir. Sistemden alacaklı olan üye, alacağını tek seferde değil, 12 ay içinde birden fazla barter işleminde üyelerden mal ve/veya hizmet elde ederek tahsil edebilmektedir. Bu noktada, yapilan barter işlemlerinden elde edilen mal ve/veya hizmetlerin toplam değerinin sistemden alacağ karşılayacak değerde olması önemlidir.

Barter işleminde mal ve/veya hizmet elde eden üyenin borcunun konusu, kural olarak para değil, kendisi tarafindan barter sisteminde arz edilen ve borcunu sona 
erdirecek değerde olan herhangi bir mal ve/veya hizmettir. Sisteme borçlanan üye, borcunu tek seferde değil, 12 ay içinde birden fazla barter işleminde üyelere mal ve/veya hizmet sunarak ödeyebilmektedir. Bu noktada, yapılan barter işlemlerinde sunulan mal ve/veya hizmetlerin toplam değerinin sisteme borcu sona erdirecek değerde olması önemlidir.

Barter işleminde para, kural olarak borç konusu olmasa da arızi şekilde borca konu olabilmektedir. Çünkü barter işleminde mal ve/veya hizmet elde eden üye, barter sistemine olan borcunu 12 ay içinde üyelere mal ve/veya hizmet sunarak ödeyemezse, bu süre sonunda barter şirketine nakit olarak ödemek mecburiyetindedir. Başka bir deyişle, 12 ay içinde üyelere mal ve/veya hizmet sunma borcu, bütün üyelerin çıkarlarının korunabilmesi için bu süre sonunda para borcuna dönüşmektedir.

Barter sistemine mal ve/veya hizmet sunma borcu olan üyenin borcu para borcuna dönüşmeden önce, borçlu üyenin borcunun alacaklısı, 12 ay içinde mal ve/veya hizmet sunacağı sistemdeki herhangi bir üyedir. Dolayısıyla 12 ayın sonunda doğan para borcunun alacaklısı, parayı tahsil eden barter şirketi değil, sistemdeki bütün üyelerdir. Barter şirketi, sadece sistemdeki bütün üyeler adına tahsil konusunda temsilci sıfatıyla bu borcu parasal olarak tahsil etmektedir. Barter şirketinin üyeleri temsil yetkisi, üyelerle yaptığı Genel Üyelik Sözleşmesi'nden doğmaktadır. Ayrıca üyelik sözleşmesi, 12 ayın sonunda doğan para borcunun da kaynağıdır. Para borcunun ne zaman doğacağı, üyelik sözleşmesinde barter şirketi tarafından kararlaştırılmaktadır. 12 ayın sonunda borçlu üyeden tahsil edilen para, barter şirketi nezdinde gerekli durumlarda kullanılmak üzere tutulmaktadır.

Para, barter sisteminde ortak bir değer ölçüsü olarak kullanılmaktadır. Paranın bu işlevinden hem barter işlemlerine konu olan mal ve/veya hizmetlerin karşılıkları ifade edilirken hem de sistemdeki üyelerin cari hesaplarındaki alacak-borç kayıtları tutulurken yararlanılmaktadır. Bu alacak-borç kayıtları, ABD doları veya Euro gibi yabancı para birimlerine endeksli barter doları cinsinden para olarak ifade edilmekte ve cari hesap kalemi oluşturabilmeleri için para alacağına-borcuna dönüştürülmektedir (Belen, 2007: 73-74).

Üyelerin cari hesaplarındaki alacak-borç kayıtları, barter işlemleri esnasında düzenlenen barter çekleri dikkate alınarak tutulmaktadır. Barter çeki, barter sisteminde hem ispat hem de ödeme aracı olarak kullanılmaktadır. İspat aracı olarak üzerinde yazılı olan değer, konusu mal ve/veya hizmet olan bir barter işlemi yapıldığını göstermektedir. Ödeme aracı olarak üzerinde yazılı olan değer ise barter işlemine konu olan mal ve/veya hizmetin değerini göstermektedir. Barter çeki, barter işleminde mal ve/veya hizmet elde eden üye tarafından bir nüshası kendinde kalmak, diğer iki nüshası ise kendisine mal ve/veya hizmet sunan üyeye ve bu işlemi cari hesaplara kaydedecek olan barter şirketine teslim edilmek üzere toplam üç nüsha halinde düzenlenmektedir. Düzenlenen çek barter işleminde mal ve/veya hizmet sunan üyeye ve barter şirketine teslim edildiğinde, yapılan işlem açısından ödeme tamamlanmış olmaktadır. Çünkü bu çek, barter 
işleminde mal ve/veya hizmet sunan üyenin cari hesabına alacak kaydı, mal ve/veya hizmet elde eden üyenin cari hesabına ise borç kaydı düşülmesini sağlamaktadır.

\section{Barter Sistemi İle İlgili Yapılmış Bazı Çalışmaların İncelenmesi}

\subsection{Araştırmanın Yöntemi}

Çalışmanın bu bölümünde barter sistemi ile ilgili yapılmış bazı çalışmalardaki açıklamalar incelenerek, sistemle doğrudan bağdaştırılamayacak noktalar tespit edilmeye çalışılmıştır.

\subsection{Araştırmanın Sorusu}

Bu çalışma kapsamında aşağıdaki soruya cevap aranması hedeflenmektedir;

-Barter sistemi ile ilgili yapılmış bazı çalışmalardaki açıklamalarda sistemle doğrudan bağdaştırılamayacak noktalar nelerdir ve bu noktalar aslında nasıl değerlendirilmelidir?

\subsection{Araştırmanın Bulguları}

\begin{tabular}{|c|c|}
\hline $\begin{array}{l}\text { Barter Sistemiyle Doğrudan } \\
\text { Bağdaştırılamayacak Noktalar }\end{array}$ & Tespitin Yapıldığı Çalışmalar \\
\hline $\begin{array}{l}\text { Genel Üyelik Sözleşmesi'nin muhteviyatı } \\
\text { itibarıyla tipik bir vekalet sözleşmesi ve cari } \\
\text { hesap sözleşmesi gibi sözleşmeler içerdiğinin } \\
\text { ileri sürülmesi. }\end{array}$ & $\begin{array}{l}\text { Erkan, 2000a; Yardımcıŏlu, } \\
\text { 2006; Koçdoğan, 2008; Öz ve } \\
\text { Güler, 2011; Dalgıç, 2011; Uyan, } \\
2013\end{array}$ \\
\hline $\begin{array}{l}\text { Barter Sözleşmesi yapan iki taraf için alıcı ve } \\
\text { satıcı ifadelerinin kullanılması ve dolayısıyla } \\
\text { yapılan sözleşmenin tipik bir satış sözleşmesiyle } \\
\text { ilişkilendirilmesi. }\end{array}$ & 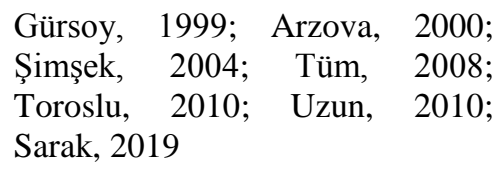 \\
\hline $\begin{array}{l}\text { Barter Sözleşmesinin tipik bir trampa (mal } \\
\text { değişim) sözleşmesi ve takas sözleşmesiyle } \\
\text { ilişkilendirilmesi. }\end{array}$ & $\begin{array}{l}\text { Özkan, 2002; Koçdoğan, 2008; } \\
\text { Özeroğlu, 2014; Sarak, } 2019\end{array}$ \\
\hline $\begin{array}{l}\text { Barter şirketi tarafından üyelere faizsiz kredi } \\
\text { (barter kredisi) sağlandığının ileri sürülmesi. }\end{array}$ & $\begin{array}{l}\text { Şimşek, 2004; Bayrav, 2009; } \\
\text { Hacicaferoğlu, 2010; Toroslu, } \\
\text { 2010; Uzun, 2010; Uyan, 2013; } \\
\text { Y1lmaz, 2018; Turay, } 2018\end{array}$ \\
\hline
\end{tabular}

\subsubsection{Bulguların Yorumlanması}

Genel Üyelik Sözleşmesi’nin muhteviyatı itibarıyla tipik bir vekalet sözleşmesi ve cari hesap sözleşmesi gibi sözleşmeler içerdiğinin ileri sürülmesi; Genel Üyelik 
Sözleşmesi, Türk hukuk sisteminde açık bir şekilde tanımlanmış sözleşme tipi değildir. Ancak TBK'nın (Türk Borçlar Kanunu) tanıdığı akit serbestisi sayesinde kanunda düzenlenmemiş bir sözleşme taraflarca tercih edilebilmektedir. Dolayısıyla üyelik sözleşmesi, TBK'daki akit serbestisi ilkesine dayanılarak yapılabilecek atipik bir sözleşme olarak kabul edilmektedir (Özkan, 2002: 72). Üyelik sözleşmesi, çeşitli sözleşmelerde öngörülen bazı hükümleri karışı bir şekilde bünyesinde barındırmaktadır. Bu bağlamda, üyelik sözleşmesi, hukuki mahiyeti itibarıyla karma nitelikli sözleşme türlerinden biri olan kombine sözleşmeler arasında mütalaa edilmektedir (Sarı, 2014: 286). Kombine sözleşmelerde bir taraf birden çok edimi yerine getirirken, diğer taraf ise genellikle belli bir miktar paranın ödenmesi gibi tek bir edimi yerine getirmektedir. Söz konusu durum, üyelik sözleşmesinde de açık bir şekilde görülmektedir (Belen, 2007: 56).

Genel Üyelik Sözleşmesi, bir bütün olarak tek bir sözleşmeyi temsil etse de temelde iki ayrı sözleşmeyi içermektedir. İlk sözleşme, barter şirketinin üyelerden aldığ 1 temsil yetkisine dayanarak üyelerin cari hesaplarının kaydını tutma, üyelerin birbirlerinden alacaklı hale gelebilmeleri için alacağın temliki veya havale işlemlerini yapma, üyeler arasında yapılan barter işlemlerine aracı olma ve üyelerin birbirlerinden olan alacaklarının takas edilmesini sağlama edimlerini kapsayan iş görme içerikli sui generis (kendine özgü yapısı olan) bir sözleşmedir. İkinci sözleşme ise üyelerin barter sisteminden alacaklarının barter şirketi tarafından garanti altına alındığı sözleşmedir ${ }^{7}$. Görüldügüu üzere barter şirketi, üyelik sözleşmesinden hareketle birden çok edimi yerine getirmektedir. Üyeler ise barter şirketinin yerine getirdiği tüm bu edimlere karşılık olarak tek bir edimi yerine getirmekte ve şirkete para (yıllık üyelik aidatı ve komisyon) ödemektedirler (Yalçınduran, 2004: 148-149).

Genel Üyelik Sözleşmesi, muhteviyatı itibarıyla vekalet sözleşmesi ve cari hesap sözleşmesi gibi sözleşmelerdeki bazı hükümleri karışık bir şekilde bünyesinde barındırmaktadır. TBK'nın 502. maddesine göre vekalet sözleşmesi, “Vekalet sözleşmesi, vekilin vekalet verenin bir işini görmeyi veya işlemini yapmayı üstlendiği sözleşmedir. Vekalete ilişkin hükümler, niteliklerine uygun düştükleri ölçüde, bu Kanunda düzenlenmemiş olan iş görme sözleşmelerine de uygulanır. Sözleşme veya teamül varsa vekil, ücrete hak kazanır." (TBK, m. 502) şeklinde tanımlanmaktadır. Barter şirketi, üyelik sözleşmesi gereğince üyelerin barter sistemine dahil olmalarını sağlamakta, üyelere cari hesap açmakta ve bu hesapların kaydını tutmakta, üyelerin arztalep bilgilerini toplayıp bilgi bankasında yayınlamakta ve üyeler arasında yapılan barter işlemlerine aracı olmaktadır. Barter şirketi, tüm bu işlemleri üyelerin menfaatlerini gözeterek yapmaktadır. Bu yönüyle, üyelik sözleşmesinin vekalet sözleşmesine ait bazı

7 Barter şirketinin Genel Üyelik Sözleşmesi kapsamında verdiği garanti, üyelerin birbirlerinden alacaklarına bizzat kefil olması anlamına gelmemelidir. Burada verilen garanti, alacakların barter sisteminden mal ve/veya hizmet şeklinde tahsil edilebileceğine dair verilen bir garantidir. Dolayısıyla barter şirketi ve üyeler arasındaki ilişkiye yönelik olarak kefalet sözleşmesinden doğan bir ilişki nitelendirmesi yapmak mümkün değildir. 
hükümleri bünyesinde barındırdığı anlaşılmaktadır. Ancak üyelik sözleşmesinin vekalet sözleşmesinden ayrıldığı bazı noktalar bulunmaktadır. Örneğin, vekalet sözleşmesinde vekil, müvekkile karş1 "talimata uygun ifa, şahsen ifa, sadakat ve özen gösterme, hesap verme, vekaleten aldıklarını müvekkile verme” (TBK, m. 505-509) gibi sorumluluklar taşımaktadır. Üyelik sözleşmesinde ise barter şirketinin taşıdığı sorumluluklar, üyelere karşı tipik bir vekil gibi çeşitli edimleri yerine getirmekle değil, sistemin işleyişine ilişkin temel faaliyetleri yürütmek ile ilgilidir. Ayrıca vekalet sözleşmesinde kural olarak ücret yoktur. Üyelik sözleşmesinde ise ücret, olması gereken zorunlu bir unsurdur. Diğer taraftan vekalet sözleşmesinde vekaletten istifa ve azil hakkı her zaman kullanılabilmektedir. Üyelik sözleşmesinde ise üyelerin sözleşmeyi tek taraflı olarak feshetmeleri belli şartlarla sınırlandırılabildiği için bu hakkın her zaman kullanılması mümkün olmayabilmektedir ${ }^{8}$.

TTK'nın (Türk Ticaret Kanunu) 89. maddesine göre cari hesap sözleşmesi, “İki kişinin herhangi bir hukuki sebep veya ilişkiden doğan alacaklarını teker teker ve ayrı ayrı istemekten karşılıklı olarak vazgeçip bunları kalem kalem alacak ve borç şekline çevirerek hesabın kesilmesinden sonra çıkacak artan tutarı isteyebileceklerine ilişkin sözleşme cari hesap sözleşmesidir." (TTK, m. 89) şeklinde tanımlanmaktadır. Barter şirketi, Genel Üyelik Sözleşmesi gereğince üyelere cari hesap açmakta ve bu hesapların kaydını tutmaktadır. Bu yönüyle, barter şirketinin yaptığı iş, kanunda tanımlanan cari hesap sözleşmesinin içeriğini andırmaktadır. Ancak üyelere açılan cari hesap, niteliği itibarıyla kanunda tanımlanan cari hesap sözleşmesinden bazı farklılıklar taşımaktadır. Örneğin, cari hesap sözleşmesinde iki taraf bulunurken, üyelere açılan cari hesapta ise barter sistemindeki bütün üyeler taraf olarak bulunmaktadır. Ayrıca cari hesap sözleşmesinde iki tarafın alacakları her zaman karşılıklı olurken, barter işlemlerinde (barter sözleşmeleri) ise üyelerin alacakları genellikle karşılıklı olmamaktadır. Çünkü barter işleminde mal ve/veya hizmet sunan üyenin, yaptığı sunumdan doğan alacak hakkını sistemdeki herhangi bir üyeden talep etme hakkı vardır. Sonuç olarak, cari

8 Barter şirketiyle üye arasında imzalanan Genel Üyelik Sözleşmesi’nin süresi bir yıldır. Sözleşme süresinin bitiş tarihinden otuz gün önce barter şirketi veya üye sözleşmeyi feshederse, barter sistemine üyelik sona ermektedir. Sisteme üyeliği sona erdiren diğer durum, üyelik sözleşmesinin tek taraflı olarak feshedilmesidir. Tek taraflı fesih, genellikle üyelik sözleşmesinden doğan yükümlülüklere aykırı davranılması durumunda gündeme gelmektedir. Örneğin, barter işleminde mal ve/veya hizmet sunan üye, karşısındaki üyeye piyasa fiyatlarına kıyasla fahiş fiyat teklif ederse veya yıllık üyelik aidatını ve komisyonları barter şirketine ödemezse, üyelik sözleşmesinden doğan yükümlülüklerini yerine getirmemiş olmaktadır. $\mathrm{Bu}$ durumda üyelik sözleşmesi, barter şirketi tarafindan tek taraflı olarak feshedilebilmektedir. Yine aynı şekilde barter şirketi, üyenin cari hesabını tutmazsa veya arz-talep bildirimlerini bilgi bankasında yayınlamazsa, üyelik sözleşmesinden doğan yükümlüklerini yerine getirmemiş olmaktadır. Bu durumda üyelik sözleşmesi, üye tarafından tek taraflı olarak feshedilebilmektedir. Ayrıca üye, cari hesabı sıfir bakiye verdiği hallerde de istediği zaman üyelik sözleşmesini tek taraflı olarak feshedebilmektedir. Sisteme üyeliği sona erdiren son durum ise iki taraflı fesihtir. İki taraflı fesih, barter şirketi ve üyenin karşlıklı rızalarıyla üyelik sözleşmesini sona erdirmeleridir. 
hesap sözleşmesinde iki tarafın alacaklarının cari hesap dönemi sonunda ayrı bir takas beyanına ihtiyaç duyulmaksızın kendiliğinden takas edilmiş sayılmaları şeklindeki özel hükmün sistemde üyelere açılan cari hesap için uygulanamayacağı açıktır.

Buraya kadar yapılan açıklamalardan hareketle Genel Üyelik Sözleşmesi'nin vekalet sözleşmesi ve cari hesap sözleşmesi gibi sözleşmelerdeki hükümleri aynen bünyesinde barındırmadığı anlaşılmaktadır. Başka bir deyişle, barter şirketiyle üyeler arasındaki ilişkiler, bu sözleşmelerden doğan ilişkileri kısmen andırmaktadır. Dolayısıyla üyelik sözleşmesi, bahse konu sözleşmelerdeki hükümleri karışık bir şekilde bünyesinde barındıran atipik bir sözleşme olarak dikkate alınmalıdır.

Barter Sözleşmesi yapan iki taraf için alıcı ve satıcı ifadelerinin kullanılması ve dolayısıyla yapılan sözleşmenin tipik bir satış sözleşmesiyle ilişkilendirilmesi; TBK'nın 207. maddesine göre satış sözleşmesi, "Satış sözleşmesi, satıcının, satılanın zilyetlik ve mülkiyetini alıcıya devretme, alıcının ise buna karşıllk bir bedel (para) ödeme borcunu üstlendiği sözleşmedir.” (TBK, m. 207) şeklinde tanımlanmaktadır. Barter sözleşmesinde para, değişim aracı olarak değil, değer ölçüsü olarak kullanılmaktadır. $\mathrm{Bu}$ husus, barter sözleşmesinin tipik bir satış sözleşmesine benzetilmesine neden olmaktadır. Oysa barter sözleşmesi, bir malın parayla değiştirildiği satış sözleşmesine şekil verebileceği gibi, bir işin görüldüğü vekalet sözleşmesine veya bir eserin meydana getirildiği istisna sözleşmesine de şekil verebilir. Ancak bu durumda da yapılan barter sözleşmesi, tipik bir satış, vekalet veya istisna sözleşmesi olarak nitelendirilememektedir (Belen, 2007: 13). Ayrıca satış sözleşmesinde borcun konusu paradır. Barter sözleşmesinde ise borcun konusu, kural olarak para değil, herhangi bir mal ve/veya hizmettir. Diğer taraftan satış sözleşmesinde alıcı, ödemesini malını satın aldığı tarafa yapmakla mükelleftir. Barter sözleşmesinde ise ihtiyaç duyduğu mal ve/veya hizmeti elde eden üye, ödemesini bu mal ve/veya hizmeti kendisine sunan tarafa yapmak zorunda değildir.

Barter Sözleşmesinin tipik bir trampa (mal değişim) sözleşmesi ve takas sözleşmesiyle ilişkilendirilmesi; TBK'nın 282. maddesine göre trampa sözleşmesi, "Mal değişim sözleşmesi, taraflardan birinin diğer tarafa bir veya birden çok şeyin zilyetlik ve mülkiyetini, diğer tarafin da karşı edim olarak başka bir veya birden çok şeyin zilyetlik ve mülkiyetini devretmeyi üstlendiği sözleşmedir.” (TBK, m. 282) şeklinde tanımlanmaktadır. Barter sözleşmesinde paranın zorunlu bir unsur olarak yer almaması, bu sözleşmenin trampa sözleşmesine benzetilmesine neden olmaktadır. Oysa barter sözleşmesinden doğan alacak-borç ilişkisi, trampa sözleşmesinde olduğu gibi genellikle karşılıklı değildir. Başka bir deyişle, barter sözleşmesi, alacak-borç ilişkisi itibarıyla trampa sözleşmesinden farklı olarak kendine özgü bir karşılıklılık içermektedir. Buna göre barter sözleşmesinde edimi yerine getiren üye, edimi elde eden üyeden herhangi bir alacak hakkı elde etmemektedir. Trampa sözleşmesinde ise iki taraf, birbirine karşı edim yerine getirmekle yükümlüdür. Ayrıca barter sözleşmesi atipik, trampa sözleşmesi ise tipik bir sözleşmedir. Diğer taraftan barter sözleşmesinde alacaklı üyenin alacak hakkının ne olduğu ve sistemde kime karşı ileri sürülebileceği net 
olarak belirlenmemişken, trampa sözleşmesinde ise bu durum net olarak belirlenmiştir. $\mathrm{Bu}$ ve benzeri farklılıklardan hareketle barter sözleşmesinde trampa sözleşmesinin içeriğinin tam olarak olmadığı anlaşılmaktadır.

TBK'nın 139. maddesinde takas ile ilgili, “İki kişi, karşılıklı olarak bir miktar para veya özdeş diğer edimleri birbirine borçlu oldukları takdirde, her iki borç muaccel ise her biri alacağını borcuyla takas edebilir. Alacaklardan biri çekişmeli olsa bile takas ileri sürülebilir. Zamanaşımına uğramış bir alacă̆ın takası, ancak takas edilebileceği anda henüz zamanaşımına uğramamış olması şartıyla ileri sürülebilir." (TBK, m. 139) açıklaması yer almaktadır. Takas, niteliği itibarıyla TBK'daki klasik sözleşmeler gibi bir sözleşme değil, daha önce aralarında hukuki ilişki bulunan iki tarafın karşılıklı ve özdeş borçlarının birbirini düşürmesini sağlayan bir haktır. Anlaşılacağı üzere takasın yapılabilmesi için, birbirinden alacaklı ve borçlu durumda olan iki tarafın bulunması ve bunların borçlarının özdeş olması gibi belli şartların varlığı gereklidir. Barterin kelime anlamlarından biri takas olduğu için barter sözleşmesi ve bir hak olan takas birbirine benzetilmektedir. Oysa takasta iki taraf arasında daha önce kurulmuş ve devam eden bir hukuki ilişki bulunurken, barter sözleşmesinde ise iki taraf ilk kez bir araya gelmektedir. Ayrıca takasta iki tarafın alacak ve borçlarının karşılıklı olması gerekirken, barter sözleşmesinde ise bu karşılıklılık gerekli değildir. Diğer taraftan borcun konusu, takasta genellikle para olurken, barter sözleşmesinde ise kural olarak para olmamaktadır.

Buraya kadar yapılan açıklamalardan hareketle barter sözleşmesinin tipik bir satış sözleşmesi, trampa sözleşmesi ve takas sözleşmesiyle ilişkilendirilemeyeceği anlaşılmaktadır.

Barter şirketi tarafindan üyelere faizsiz kredi (barter kredisi) sağlandı̆̆ının ileri sürülmesi; Barter sisteminin işleyişinde böyle bir durum söz konusu değildir. Çünkü sistemdeki üyeler, barter şirketinin kendilerine sağladığı bir krediyi değil, kendi yarattıkları krediyi kullanmaktadırlar. Başka bir deyişle, üyeler, daha önce barter işlemlerinde üyelere mal ve/veya hizmet sunmaları veya barter şirketine teminat vermeleri dolayısıyla bu krediye sahip olmaktadırlar.

\section{Sonuç}

Türkiye'de barter sistemine ilişkin özel bir hukuki düzenleme henüz mevcut değildir. Ayrıca hali hazırda faaliyet gösteren barter şirketlerinin çoğu, sistem hakkında doğru ve anlaşılır bilgi sağlama noktasında gerekli özeni göstermemektedir. $\mathrm{Bu}$ iki durum, sistemin hem hukuki mahiyetinin ne olduğu hem de pratikte nasıl uygulandığ konusunda akademik çalışmalarda yapılan açıklamalarda aslıyla uyuşmazlıklara sebebiyet vermektedir. Nitekim yukarıda ortaya konulan araştırma bulgularında da açıkça görüldüğü üzere bu çalışma kapsamında incelemeye tabi tutulan akademik çalışmalardaki açıklamalar, genel anlamda barter sisteminin kendine özgü hukuki mahiyeti ve kredilendirme ilkesiyle tam anlamıla örtüşmemektedir. 
Barter sistemi, günümüzde TTK ve TBK gibi farklı kanunlardaki hükümlerin Genel Üyelik Sözleşmesi’ne kıyasen uygulanmasıyla işlemektedir. Yani TTK ve TBK'da yer alan bazı hükümler, günümüzde sistemin işleyişine hukuki dayanak teşkil etmektedir. Dolayısıyla sisteme ilişkin özel bir hukuki düzenlemenin yapılmasının gerekli olmadığı düşünülebilir. Ancak böyle bir düzenlemenin yapılması, sistemin hukuki mahiyetinin ne olduğu konusuna açıklık getirecektir. Bu noktada barter şirketlerinin, sistem hakkındaki bilgilendirme faaliyetlerinde gerekli özeni göstermeleri de sistemin Türkiye'de daha doğru ve anlaşılır bir şekilde bilinmesine ve böylelikle güvenilirliğini artırıp kullanımının işletmeler arasında daha yaygın hale gelmesine katkı sunabilecektir.

$\mathrm{Bu}$ çalışmadan hareketle yabancı ülkelerde barter sisteminin hukuki mahiyetinin ne olduğunu ve pratikte nasıl uygulandığını inceleyen çalışmalar yapılarak, Türkiye'yle benzerlik ve farklılık taşıyan noktalar ortaya konulabilir.

\section{Kaynakça}

Arzova, B. (2000). Barter Işslemleri-Işsleyişi, Hukuki Yönü ve Muhasebeleştirilmesi. İstanbul: Türkmen Kitabevi.

Aşar, A. O. (2016). Türkiye'de Takas Sistemi ve Uygulamadaki Problemlerle İlgili Bir Araştırma. Yayımlanmamış Yüksek Lisans Tezi. İstanbul: İstanbul Ticaret Üniversitesi. Sosyal Bilimler Enstitüsü.

Avery, R., Bezmez, S., Edmonds, A. G., \& Yaylalı, M. (1996). Ingilizce-Türkçe Redhouse sözlüğü (25th ed.). İstanbul: Redhouse Yayınevi.

Bayrav, M. H. (2009). Alternatif Ticaret ve Finansman Tekniği Olarak Barter Sistemi. Yayımlanmamış Yüksek Lisans Tezi. İstanbul: Marmara Üniversitesi. Sosyal Bilimler Enstitüsü.

Belen, H. (2007). Barter Sistemi, Hukuki Yapısı ve İşleyişi. İstanbul: Beta Yayınları.

Boonstra, L., Klamer, A., Karioti, E., Do Carmo, A., \& Geenen, S. (2013). Complementary Currency Systems Social and Economic Effects. Rotterdam.

Camız, R. (2015). Milletlerarası Özel Hukukta Barter Sözleşmeleri. Yayımlanmamış Yüksek Lisans Tezi. Kayseri: Erciyes Üniversitesi. Sosyal Bilimler Enstitüsü.

Dalgıç, N. (2011). Ulusal ve Uluslararası Finansman Aracı Olarak Barter ve Türkiye Örneği. Yayımlanmamış Yüksek Lisans Tezi. İstanbul: Haliç Üniversitesi. Sosyal Bilimler Enstitüsü. 
Demir, M., \& Ürgüp, S. E. (2014). Barter Sisteminin İşletmelerin Finansal Başarıları Üzerine Etkisinin Oran Analiziyle İncelenmesi: Bist'te Uygulama. Bingöl Üniversitesi Sosyal Bilimler Enstitüsü Dergisi, 4(8), 31-52.

Dorcpalam, D. (2007). Yeni Bir Finansman Aracı Olarak Barter (Takas) Sistemi ve Muhasebeleştirilmesi. Yayımlanmamış Yüksek Lisans Tezi. İzmir: Dokuz Eylül Üniversitesi. Sosyal Bilimler Enstitüsü.

Erkan, M. (2000a). Yeni Bir Finansman Aracı: Barter. Vergi Dünyası, (221), 92-103.

Erkan, M. (2000b). Yeni Bir Finansman Aracı Olarak Barter'ın, Diğer Finansman Teknikleri ile Karşılaştırılması. Active Bankacılık ve Finans Dergisi, 2(12), 1-8. http://www.erkymm.com/resimler/Bartern_Dier_Finansman_Teknikleri_le_KaA laAtrlmas_ACTIVE_NISAN_MAYIS_2000.pdf, Erişim Tarihi: 19 Temmuz 2020 .

Global Barter. Barter Nasıl İşler?. http://www.globaltakas.com/global-barter-nasil-isler, Erişim Tarihi: 31 Temmuz 2020.

Güdelci, E. N. (2020). Bobi FRS Açısından Barter İşlemleri ve Muhasebeleştirilmesi. Aksaray Üniversitesi İktisadi ve İdari Bilimler Fakültesi Dergisi, 12(3), 61-72.

Güler, E. (2004). Barter Işslemleri ve Türkiye'de Uygulamanın Değerlendirilmesi. Yayımlanmamış Yüksek Lisans Tezi. Konya: Selçuk Üniversitesi. Sosyal Bilimler Enstitüsü.

Gürsoy, C. (1999). Barter El Kitabl-Dünyada ve Türkiye’de Barter (Takas) Ticareti. Bursa: Akmat Akığlu Matbaacılık.

Hacıcaferoğlu, B. (2010). Barter (Takas) Sistemi ve Sporda Kullanılabilirliği: Spor Kulüp Yöneticilerinin Görüşleri. Yayımlanmamış Doktora Tezi. Ankara: Gazi Üniversitesi. Sağlık Bilimleri Enstitüsü.

IRTA. (2020). The Barter and Trade Industry. https://www.irta.com/about/the-barterand-trade-industry/, Erişim Tarihi: 18 Şubat 2020.

Karyağdı, N. G. (2014). Tarım Alet ve Makine Üretimi Yapan İşletmelerin Ekonomik Yapısı, Muş İlinde Bir Araştırma. Atatürk Üniversitesi Sosyal Bilimler Enstitüsü Dergisi, 18(1), 405-424.

Keskin, A. D. (2004). Barter Sözleşmesi. Ankara: Yetkin Hukuk Yayınları.

Kırlıoğlu, H., \& Bağdat, A. (2016). Barter İşlemlerinin Gelişimi ve Günümüzdeki Yeri. Uluslararası Muhasebe ve Finans Araştırmaları Kongresi (ICAFR 16)-SPECİAL ISSUE, 643-653. Zonguldak: Bülent Ecevit Üniversitesi. 

Calıșmalar Üzerine Bir İnceleme

Koç, E. (2008). Takas Büyümüş Barter Olmuş. Hukuk Gündemi Dergisi, (9), 30-35.

Koçdoğan, A. (2008). Bir Finansman Tekniği Olarak Barter Sistemi ve İslam Hukukundaki Yeri. Yayımlanmamış Yüksek Lisans Tezi. Bursa: Uludağ Üniversitesi. Sosyal Bilimler Enstitüsü.

Mert, H., \& Dukan, O. (2017). Barter İşlemleri ve Uluslararası Muhasebe Standartlarına Göre Muhasebeleştirilmesi. Afyon Kocatepe Üniversitesi Sosyal Bilimler Dergisi, 19(2), 1-21.

Oduncuoğlu, F. (2007). Konaklama İşletmelerinde Barter Sistemi Uygulamasının Pazarlama Fonksiyonuna Etkisinin Analizi "Barter Sistemine Üye Olan Konaklama İşletmelerine Yönelik Bir Uygulama.” Yayımlanmamış Yüksek Lisans Tezi. Eskişehir: Anadolu Üniversitesi. Sosyal Bilimler Enstitüsü.

Öz, E., \& Güler, A. (2011). Barter Sistemi ve Vergilendirme. Vergi ve Vergi Politikası Üzerine Incelemeler içinde. Bursa: Ekin Yayınevi.

Öz, Y., \& Dursun, A. (2005). Bir Finansman Aracı Olarak Barter ve Türkiye'deki İşletmelerde Finansman Amaçlı Kullanımı. Ekev Akademi Dergisi, 9(25), 307320 .

Özeroğlu, A. İ. (2014). Barter'ın Türk Finans Sektöründeki Yeri ve Uygulanabilirliği. Uluslararası İktisadi ve İdari Incelemeler Dergisi, 7(13), 115-132.

Özkan, A. (2002). Barter İşlemleri ve Muhasebe Uygulamaları. Erciyes Üniversitesi İktisadi ve İdari Bilimler Fakültesi Dergisi, (18), 63-86.

Özkoçak, M. O. (2011). Barter Sisteminin Eskişehir'de Kullanılmamasının Nedenleri: Eskişehir Organize Sanayi Bölgesi’nde Bir Araştırma. Yayımlanmamış Yüksek Lisans Tezi. Eskişehir: Anadolu Üniversitesi. Sosyal Bilimler Enstitüsü.

Paya, M. M. (2013). Para Teorisi ve Para Politikası. İstanbul: Türkmen Kitabevi.

Referans Barter. Barter Nasıl İşler?. http://www.referansbarter.com.tr/barter-nasil-isler2-4.aspx, Erişim Tarihi: 29 Temmuz 2020.

Saka, N. (2017). Barter Sözleşmesi. Yayımlanmamış Yüksek Lisans Tezi. İstanbul: İstanbul Ticaret Üniversitesi. Sosyal Bilimler Enstitüsü.

Sarak, G. (2019). Türk Finans Sektöründe Barter Sisteminin Uygulanabilirliği ve Vergisel Boyutu. Yayımlanmamış Yüksek Lisans Tezi. Aydın: Aydın Adnan Menderes Üniversitesi. Sosyal Bilimler Enstitüsü. 
Sarı, M. (2014). Barter Şirketleri, Üyelik İlişkisi Sebebiyle, Üyelerinin Borçlarından Dolayı Haciz İhbarnameleriyle Sorumlu Tutulabilir Mi? Terazi Hukuk Dergisi, 9(100), 285-290.

Serozan, R. (2012). Atipik Trampa Sözleşmeler. Banka ve Ticaret Hukuku Dergisi, 28(4), 5-26.

Sürmen, Y., \& Kaya, U. (2001). Barter ve Muhasebe İşlemleri. Vergi Dünyası, (239), 130-139.

Şenol, A. (1999). Barter Sisteminin İşleyişi Uygulama ve Muhasebesi. Yayımlanmamış Yüksek Lisans Tezi. Sakarya: Sakarya Üniversitesi. Sosyal Bilimler Enstitüsü.

Şimşek, M. S. (2004). Parasız Ticaret Barter. İstanbul: Kapital.

Tekşen, Ö. (2006). Barter Işslemlerinin Muhasebeleştirilmesi ve Vergilendirilmesinin Yeni Finansal Tekniklerle Karşılaştırllarak Incelenmesi: Bir Araştırma. Yayımlanmamış Doktora Tezi. Isparta: Süleyman Demirel Üniversitesi. Sosyal Bilimler Enstitüsü.

Toroslu, M. V. (2010). Barter Işlemleri ve Muhasebesi. Ankara: Adalet Yayınevi.

Tucker, I. B. (2010). Economics for Today (7th ed.). Ohio: South-Western Cengage Learning.

Turay, F. (2018). Finansal Açıdan İslam Borçlar Hukuku. Yayımlanmamış Doktora Tezi. Erzurum: Atatürk Üniversitesi. Sosyal Bilimler Enstitüsü.

Tüm, K. (2008). Barter Sistemi ve Muhasebe Uygulamaları. Çukurova Üniversitesi IIBF Dergisi, 12(1), 1-18.

Türk Barter. Dünya Barter Birliği (IRTA). http://www.turkbarter.com/page/irta, Erişim Tarihi: 08 Temmuz 2020.

Türk Borçlar Kanunu. (2011). 6098 sayılı Türk Borçlar Kanunu. Resmi Gazete, 5(27836), 10757-10870.

Türk Ticaret Kanunu. (2011). 6102 sayılı Türk Ticaret Kanunu. Resmi Gazete, 50(27846), 10975-11310.

Uyan, Ö. (2013). Alternatif Bir Ticaret Modeli ve Finansman Aracı Olarak Barter Sistemi ve Türkiye'deki Barter Uygulamaları. Yayımlanmamış Yüksek Lisans Tezi. İstanbul: İstanbul Aydın Üniversitesi. Sosyal Bilimler Enstitüsü. 
Uzun, F. (2010). Barter Sistemi ve Küçük ve Orta Boy İşletmelerde Uygulanabilirliği: Türkiye Örneği. Yayımlanmamış Yüksek Lisans Tezi. Ankara: Gazi Üniversitesi. Sosyal Bilimler Enstitüsü.

Yalçınduran, T. (2004). Barter Sözleşmesi. Banka ve Ticaret Hukuku Dergisi, 22(4), 141-176.

Yardımcıŏlu, M. (2006). Bir Finansal Tekniğin Muhasebe Disiplini Yönünden İrdelenmesi: Barter. Selçuk Üniversitesi Karaman I.İ.B.F. Dergisi, (10), 115-127.

Yılmaz, F. (2018). Barter Uygulamaları ve Muhasebeleşme Süreçleri. Yayımlanmamış Yüksek Lisans Tezi. İstanbul: İstanbul Üniversitesi. Sosyal Bilimler Enstitüsü.

Yolaçan, N. (2010). Barter Sistemi ve Türkiye'de Hizmet Sektöründe Bir Uygulama. Yayımlanmamış Yüksek Lisans Tezi. İstanbul: Marmara Üniversitesi. Sosyal Bilimler Enstitüsü. 